\title{
Release of Soluble Receptors for Tumor Necrosis Factor (TNF) in Relation to Circulating TNF during Experimental Endotoxinemia
}

\author{
Giatgen A. Spinas, * Ulrich Keller, * and Manfred Brockhaus* \\ ${ }^{*}$ Department of Internal Medicine and Research, University Hospital, 4031 Basel, Switzerland; and ${ }^{\ddagger} F$. Hoffmann-La Roche Ltd., \\ Pharmaceutical Research-New Technologies, 4002 Basel, Switzerland
}

\begin{abstract}
Serial plasma samples from human volunteers obtained after intravenous administration of Escherichia coli endotoxin were analyzed for the presence of circulating soluble tumor necrosis factor receptors (sTNFR). A four- to fivefold increase of type $A$ (p75) and type B (p55) sTNFR was observed 3 h after endotoxin challenge. Pretreatment of the volunteers with ibuprofen before the injection of endotoxin resulted in a slight increase (3.87 \pm 0.2 vs. $3.27 \pm 0.3 \mathrm{ng} / \mathrm{ml})$ and temporal shift of sTNFRA release concurrent to a marked augmentation of TNF levels $(603 \pm 118 \mathrm{vs} .338 \pm 56 \mathrm{pg} / \mathrm{ml})$ as compared to the group without ibuprofen pretreatment. There was a significant correlation between peak sTNFR-A levels and peak TNF levels in the individual probands $(r=0.52, P=0.04)$. On the contrary, release kinetics and plasma concentrations of STNFR-B were identical in both groups $(7.38 \pm 0.69 \mathrm{vs} .7 .44 \pm 0.33 \mathrm{ng} / \mathrm{ml})$ and no correlation with individual TNF levels was observed. The amount of sTNFR liberated upon endotoxin challenge was not sufficient to block TNF-mediated cytotoxic effects. Our data indicate that the release in vivo of type $A$ and type $B$ sTNFR upon a short exposure to endotoxin is regulated differently. $(J$. Clin. Invest. 1992. 90:533-536.) Key words: lipopolysaccharide $\bullet$ tumor necrosis factor-binding protein $•$ human $\bullet$ ibuprofen - cyclooxygenase inhibitor
\end{abstract}

\section{Introduction}

Tumor necrosis factor $\alpha /$ cachectin (TNF) ${ }^{1}$ is a macrophage/ lymphocyte-derived cytokine with a broad spectrum of immunoregulatory, metabolic, and proinflammatory activities (1). Excessive stimulation of TNF-secreting cells by endotoxin leads to a high systemic TNF concentration which is believed to be the main pathogenic factor for hemorrhagic organ failure in septic shock (2). The vascular brain damage in cerebral malaria is attributed to the activities of TNF as well (3). In view of the pathogenic consequences of excessive TNF production, one may expect that the biological activities of TNF are counteracted by serum factors that confine the proinflammatory activities of TNF to the local site of infection and restrict the systemic toxicity of the cytokine.

Significant amounts of proteins that inhibit TNF activity, termed TNF-binding proteins, have been detected in febrile patients (4), in patients undergoing hemodialysis (5), and in

Address correspondence to Manfred Brockhaus, M. D., Ph. D., Hoffmann-La Roche, Building 69/214, CH-4002 Basel, Switzerland.

Received for publication 22 August 1991 and in revised form 19 February 1992.

1. Abbreviations used in this paper: p. i., postinjection; sTNFR, soluble TNFR; TNF, tumor necrosis factor; TNFR, TNF receptor.

J. Clin. Invest.

(c) The American Society for Clinical Investigation, Inc. 0021-9738/92/08/0533/04 \$2.00

Volume 90, August 1992, 533-536 cancer patients treated with recombinant TNF (6). The inhibitory proteins bind TNF and lymphotoxin (TNF $\beta$ ); they have been identified as soluble fragments of the TNF receptor extracellular domains (sTNFR) $(7,8)$. Two types of TNF receptors with molecular masses of $75 \mathrm{kD}$ (TNFR-A) and $55 \mathrm{kD}$ (TNFR-B) are expressed in cell lines $(9,10)$ and in tissue $(11)$; synonymous names are TNFR $\alpha$, TNF-RII, or p75, and TNFR $\beta$, TNF-RI, or p 55 , respectively. Soluble fragments from both receptor types can be liberated in vitro (12) and in vivo (7). The soluble TNF-binding proteins may be one component of an autocrine and paracrine regulatory system which limits toxic effects of systemically circulating TNF.

Recently we and other investigators have reported the induction of significant levels of circulating TNF by experimental administration of Escherichia coli endotoxin to healthy volunteers (13-15). Pretreatment of the volunteers with ibuprofen, an inhibitor of prostaglandin synthesis, greatly enhanced circulating TNF concentrations $(14,15)$ while blunting the clinical response to endotoxin. TNF- and IL-1 inhibitory activities were found in several of these sera (16) suggesting that they have been the cause for the low toxicity observed in this experimental system. Here we report a detailed analysis of sTNFR-A and STNFR-B in experimental endotoxinemia and compare the formation of STNFR with the levels of TNF after administration of endotoxin.

\section{Methods}

Subjects and study protocol. 21 healthy male volunteers participated in the study to assess the effects of experimental endotoxinemia on various clinical parameters. Details of the study protocol and results have been described elsewhere (15). Briefly, one group $(n=8)$ received an intravenous (i.v.) bolus of $4 \mathrm{ng} / \mathrm{kg}$ body weight of $E$. coli endotoxin (US ref., lot EC-5; Bureau of Biologics, Food and Drug Administration, Bethesda, MD), another group $(n=7)$ was injected the same dose of endotoxin, but was pretreated with $2 \times 800 \mathrm{mg}$ ibuprofen $2 \mathrm{~h}$ before and immediately before injection of endotoxin. A control group ( $n$ $=6$ ) received an i.v. bolus of $0.9 \%$ saline. Heparin-plasma was procured rapidly and stored at $-20^{\circ} \mathrm{C}$ until use.

Assays. sTNFR-A and sTNFR-B concentrations were determined by two simultaneously performed immunoassays $(17,18)$. Briefly, 96well polyvinyl plates (Dynatech Corp., Alexandria, VA) were sensitized with affinity-purified anti-mouse Ig from rabbit ( $10 \mu \mathrm{g} / \mathrm{ml} \mathrm{PBS}$ ) followed by an anti-TNFR monoclonal antibody $(10 \mu \mathrm{g} / \mathrm{ml})$ in blocking buffer ( $50 \mathrm{mM}$ Tris/ $\mathrm{HCl} \mathrm{pH} 7.4,140 \mathrm{mM} \mathrm{NaCl}, 5 \mathrm{mM}$ EDTA, $1 \%$ delipidated milk powder). MAb utr-4 and htr-20 were used for this purpose as noninhibitory antibodies against TNFR-A and TNFR-B, respectively (9). Plasma samples diluted $1: 10(45 \mu \mathrm{l})$ were added to the wells and incubated for $3 \mathrm{~h}$ at $4^{\circ} \mathrm{C}$. The plate was washed once with PBS and ${ }^{125} \mathrm{I}$-TNF ( $50 \mu \mathrm{l}, 450 \mathrm{Ci} / \mathrm{mmol}, 10^{6} \mathrm{cpm} / \mathrm{ml}$ ) in blocking buffer was added. After $2 \mathrm{~h}$ at $4^{\circ} \mathrm{C}$ wells were washed four times with PBS and the bound radioactivity was measured in a gamma-scintillation counter. Specificity and sensitivity of the assay was verified using cell lysates and purified recombinant sTNFR (19) kindly provided by H. Loetscher (Hoffmann-La Roche, Basel, Switzerland).

Control experiments with exogenous recombinant TNF added to plasma samples taken at 180 min postinjection (p.i.) were performed to assess whether endogenously present TNF could inhibit the sTNFR signal. Plasma was preincubated with recombinant TNF at the indi- 
cated concentrations for $30 \mathrm{~min}$ and assayed for sTNFR. As seen in Fig. 1, TNF concentrations up to $10 \mathrm{ng} / \mathrm{ml}$ did not interfere with the measurements of sTNFR-A and sTNFR-B.

TNF was measured in plasma using a TNF-specific ELISA (Endogen, Inc., Boston, MA) with a detection limit of $10 \mathrm{pg} / \mathrm{ml}$ (15). Control experiments with recombinant sTNFR-A and sTNFR-B showed that TNF values, as measured by this assay, were not quenched because of the presence of sTNFR: plasma samples taken $90 \mathrm{~min}$ p.i. at peak of TNF levels showed identical TNF values with and without exogenous sTNFR-A or sTNFR-B being added at a concentration of up to 20 $\mathrm{ng} / \mathrm{ml}$ (not shown).

TNF cytotoxicity assay. Purified recombinant sTNFR-A and sTNFR-B expressed in Chinese hamster ovary cells (19) was added at the indicated concentrations to aliquots of individual plasma samples from the groups with ( $60 \mathrm{~min}$ p.i.) and without ( $90 \mathrm{~min}$ p.i.) ibuprofen pretreatment. The samples were kept $14 \mathrm{~h}$ at $4^{\circ} \mathrm{C}$ before being added to TNF-sensitive WEHI 164 cells at 1:8 dilution. Cytotoxicity was determined by 3-(4,5-dimethylthiazole-2-yl)-2,5-diphenyltetrazolium bromide (MTT) dye formation after $72 \mathrm{~h}$ (20). Cultures with plasma from both groups were compared to cultures containing the same amount of TNF-negative plasma from the $\mathrm{NaCl}$ group. Inhibition of cytotoxicity was calculated from the optical densities recorded at $570 \mathrm{~nm}$ as:

Inhibition $=\left(O D_{+ \text {sTNFR }}-O D_{- \text {sTNFR }}\right) /\left(O D_{\mathrm{NaCl}}-\mathrm{OD}_{\text {-sTNFR }}\right)$.

Data analysis. Data are expressed as mean $\pm \mathrm{SE}$, unless otherwise indicated. Analysis of variance with repeated measures and least square regression analysis was performed using the BMDP program (Statistical Software, San Francisco, CA); 5\% was chosen as the level of signifcance.

\section{Results}

Intravenous administration of endotoxin to healthy volunteers caused a marked increase of sTNFR-A and sTNFR-B (Fig. 2, $B$ and $C$ ) from baseline levels of $0.72 \pm 0.03 \mathrm{ng} / \mathrm{ml}$ and $1.98 \pm 0.15$ $\mathrm{ng} / \mathrm{ml}$, respectively, to peak concentrations of $3.27 \pm 0.30 \mathrm{ng} /$ $\mathrm{ml}$ and $7.38 \pm 0.69 \mathrm{ng} / \mathrm{ml}$, respectively. In plasma from individuals receiving saline no increase of STNFR-A or sTNFR-B above baseline levels was observed. Pretreatment with ibuprofen slightly increased sTNFR-A concentrations $(3.87 \pm 0.21$ $\mathrm{ng} / \mathrm{ml}$ vs. $3.27 \pm 0.30 \mathrm{ng} / \mathrm{ml}, P>0.001)$ and caused a $60-\mathrm{min}$ shift in the maximum release of sTNFR-A as compared to individuals without ibuprofen pretreatment (Fig. 2 B). On the other hand, plasma concentrations and release kinetics of sTNFR-B remained unchanged under the influence of ibuprofen $(7.44 \pm 0.33 \mathrm{ng} / \mathrm{ml}$ vs. $7.38 \pm 0.69 \mathrm{ng} / \mathrm{ml}$, Fig. $2 C)$.

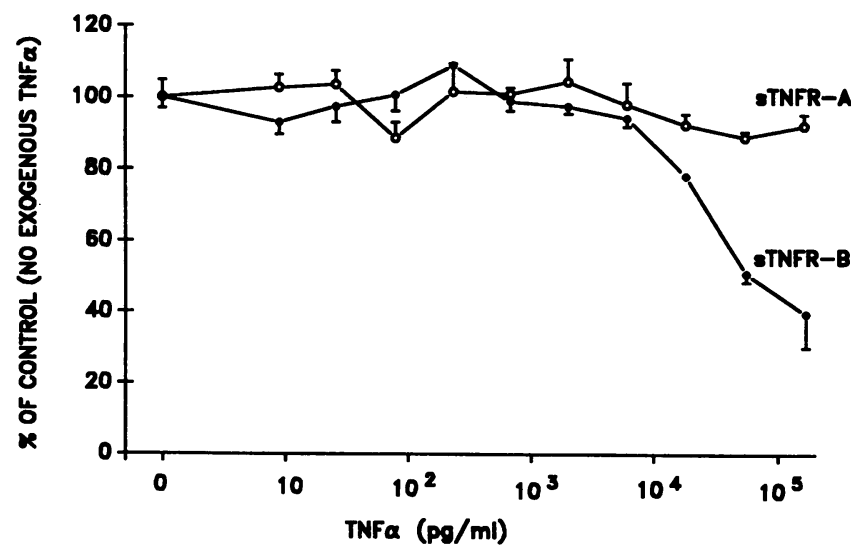

Figure 1. Influence of exogenously added TNF on the detection of sTNFR-A ( - -$)$ and sTNFR-B (-•-) . Plasma obtained 180 min after endotoxin administration was preincubated with increasing concentrations of recombinant TNF prior to the measurement of sTNFR. Data are means \pm SD of triplicate measurements.
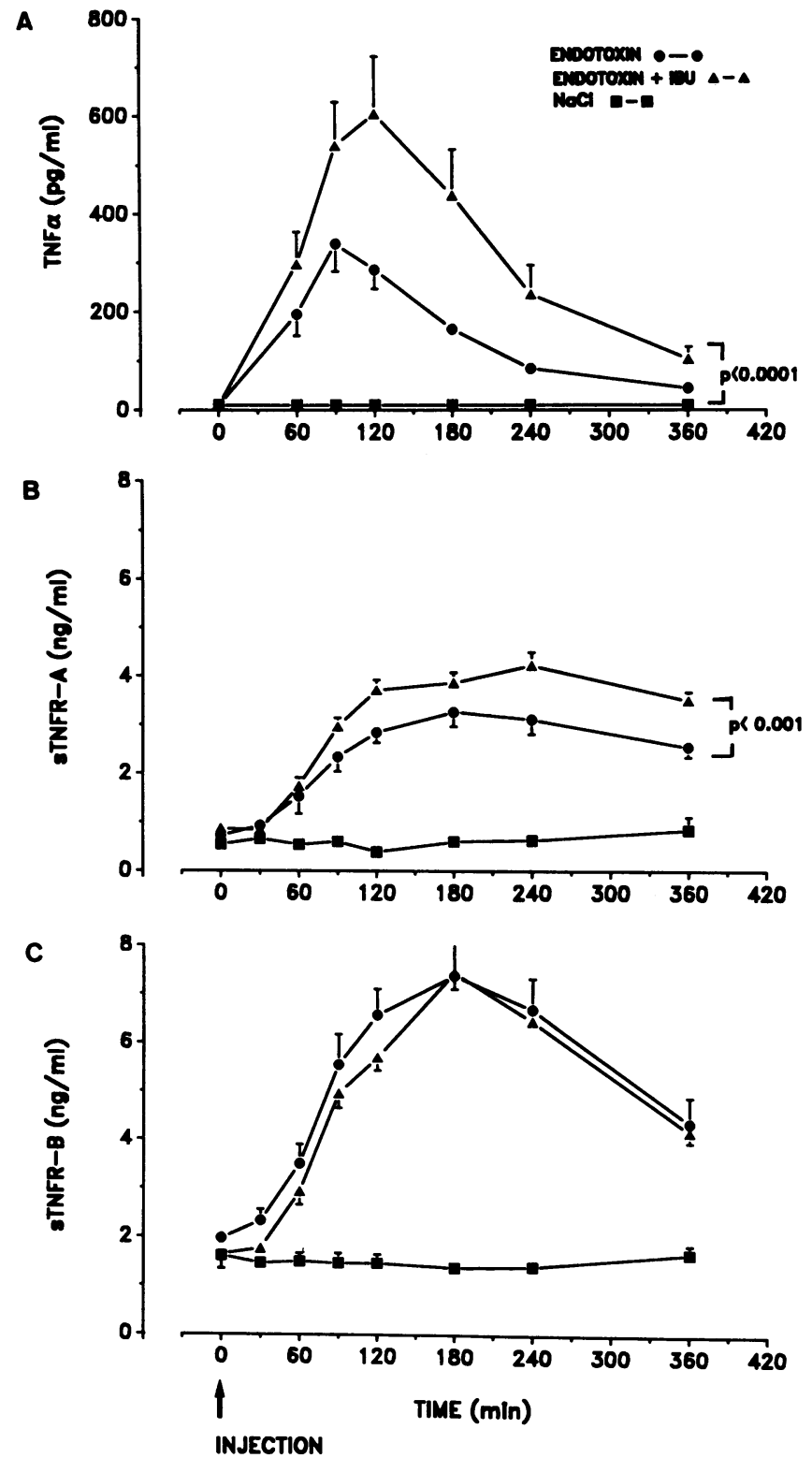

Figure 2. Concentration of TNF $(A,[15])$, sTNFR-A $(B)$, and sTNFR-B $(C)$ in plasma of humans receiving an i.v. bolus injection of endotoxin without $(-\bullet-)(n=8)$ and with ibuprofen pretreatment $(-\Delta-)(n=7)$. Controls $(-\square)(n=6)$ received saline. Endotoxin or saline were administered at time point 0 . Data are means $\pm \mathrm{SE}$

The release of sTNFR followed TNF elaboration with a 90-120-min delay, and sTNFR remained elevated in circulation until at least $6 \mathrm{~h}$ after injection of endotoxin $(2.55 \pm 0.20$ $\mathrm{ng} / \mathrm{ml} \mathrm{sTNFR-A}$ and $4.35 \pm 0.04 \mathrm{ng} / \mathrm{ml}$ sTNFR-B) at a time most TNF had disappeared from circulation. Ibuprofen pretreatment caused a marked augmentation of circulating TNF (15) paralleled only by a small but significant increase in sTNFR-A (Fig. 2, $A$ and $B$ ). In addition, peak sTNFR-A levels correlated significantly with peak TNF levels in the individual subjects $(r=0.52, P=0.04, n=15$; Fig. $3 A$ ), while no correlation was observed between peak sTNFR-B and TNF concentrations $(r=0.14, P=0.61, n=15$; Fig. $3 B)$.

In molar terms plasma TNF reached a maximum mean concentration of $35.3 \pm 7 \mathrm{pmol} /$ liter in the ibuprofen pretreated individuals. Assuming a molecular mass for sTNFR of $30 \mathrm{kD}$, 

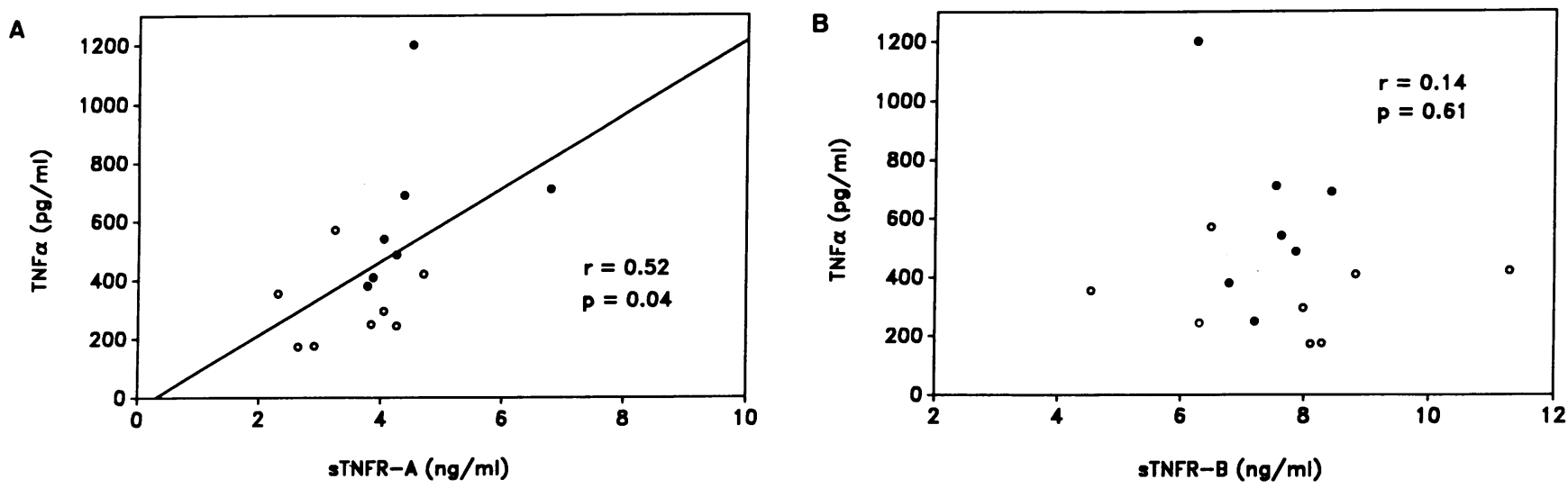

Figure 3. Relation between peak plasma concentrations of TNF and sTNFR-A $(A)$, and TNF and sTNFR-B $(B)$ in subjects receiving endotoxin without $(0)$ and with $(\bullet)$ ibuprofen pretreatment.

sTNFR-A increased from $29 \pm 4$ to $141 \pm 9$ pmol/liter and sTNFR-B from $55 \pm 10$ to $248 \pm 11 \mathrm{pmol} /$ liter being always in large excess over TNF. We therefore tested whether further addition of recombinant sTNFR influenced TNF bioactivity in plasma from individuals with and without ibuprofen pretreatment. Fig. 4 shows that recombinant sTNFR-A and sTNFR-B at the low concentration of $20 \mathrm{ng} / \mathrm{ml}(660 \mathrm{pmol} /$ liter $)$, i.e., two to three times higher than individual peak levels in our experiment, weakly inhibited the TNF mediated cytotoxicity of plasma 60 and $90 \mathrm{~min}$ after endotoxin administration. At a 10 times higher concentration of sTNFR more significant inhibition of cytotoxicity was observed. The combination of sTNFR-A and STNFR-B showed no stronger inhibition of TNF-cytotoxicity than sTNFR-B alone.

\section{Discussion}

Work from several laboratories has demonstrated the presence of TNF inhibitory proteins in blood and urine from normal individuals and from patients with infectious and malignant diseases $(4,5,7,17,21)$. TNF inhibitory proteins are derived by proteolysis ( 7 ) from the extracellular domains of two types of TNF receptors which are biochemically and immunologi-

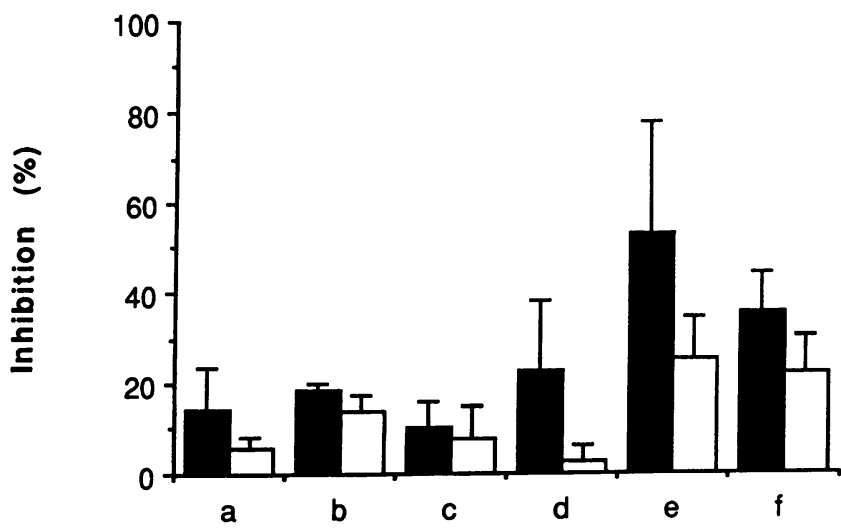

Figure 4. Cytotoxicity of TNF-containing plasma on TNF-sensitive WEHI 164 cells. Inhibition by STNFR-A $(a$ and $d)$, sTNFR-B $(b$ and $e$ ), and by the combination of STNFR-A and -B ( $c$ and $f)$ at $20 \mathrm{ng} /$ $\mathrm{ml}(a, b, c)$ and $200 \mathrm{ng} / \mathrm{ml}(d, e, f)$ concentration of each. Full bars, pooled plasma from individuals without ibuprofen pretreatment $(90$ min p.i., $380 \mathrm{pg} / \mathrm{ml}$ TNF). Open bars, pooled plasma from individuals with ibuprofen pretreatment ( $60 \mathrm{~min}$ p.i., $300 \mathrm{pg} / \mathrm{ml}$ TNF). Mean of triplicate determinations \pm SD. cally distinct proteins $(9,10)$ despite the high sequence homology within the extracellular domain (22). In this study we demonstrate that both types of STNFR are released into circulation after an i.v. bolus injection of bacterial endotoxin. The concentrations of both types of sTNFR rise four- to fivefold above baseline levels reaching their maximum values $180-240 \mathrm{~min}$ after the injection of endotoxin. STNFR-B is consistently two to three times more abundant than STNFR-A, as detected with our standards. A similar predominance of STNFR-B has been found using the same assay also in patients with various malignancies, except patients with certain B-cell leukemias where sTNFR-A was the predominant receptor type released into circulation (17).

sTNFR can be liberated from the cell surface of PMN after in vitro stimulation with the chemotactic peptide FMLP, C5a, granulocyte macrophage colony-stimulating factor, and human PMN elastase, but not with endotoxin, IFN $\gamma$, IL-1 $\beta$, or TGF- $\beta 1$ (12). The factors that are responsible for the in vivo release of sTNFR have not been identified yet. The ligand TNF has been proposed as the physiologic stimulus for the release of soluble receptors, since administration of TNF to cancer patients was followed by increased sTNFR levels $(6,23)$. Our results from endotoxinemic individuals indicate a difference in the in vivo induction mechanism for the two types of soluble receptors. The release of STNFR-A goes in parallel with TNF levels showing an increase and a temporal shift in ibuprofen pretreated individuals. In addition, there is a significant correlation between maximum TNF and maximum STNFR-A concentrations in the individual probands. However, the increase in STNFR-A due to ibuprofen pretreatment is much smaller than the concurrent increase in TNF levels. In contrast to STNFR-A, the maximum secretion and release kinetics for the type $B$ receptor remain unchanged, irrespective of a large increase in TNF production. No correlation between TNF elaboration and sTNFR-B levels could be established suggesting that endogenous TNF is not the primary stimulus for release of the type B receptor. It is possible, however, that the release of sTNFR-B did not further increase in our experiment because the secretory capacity was exhausted already at a lower TNF concentration. This explanation seems less likely since substantially higher sTNFR-B levels than the ones we find in experimental endoxinemia have been observed in various disease states (17, 21, and own unpublished data).

It has been reported that $\mathrm{PMN}$-elastase mediates shedding of TNFR-A, but not of TNFR-B, from the cell surface of acti- 
vated PMN in vitro (18). PMN-elastase was also found to be increased in plasma of the ibuprofen pretreated individuals in our experiment (15). Our data are consistent with the view that PMN-elastase in serum is responsible for the small increase in sTNFR-A levels, but not sTNFR-B levels, which we observed in ibuprofen pretreated individuals. Furthermore, we notice a clear correlation between maximum PMN-elastase concentrations and sTNFR-A, while no correlation of PMNelastase with sTNFR-B can be established (results not shown). A distinct induction mechanism for release of the two types of sTNFR is not unexpected, since differential TNF receptor expression patterns were found by immunohistochemistry, TNFR-A being mainly expressed in the T cell area and TNFR$B$ in the germinal center of lymphoid tissue (11). In addition, the expression of the two receptor types in PBL appears to be regulated differentially (22).

In molar terms the maximum concentration of sTNFR produced in response to an endotoxin stimulus is three to eight times higher than the respective TNF concentration (240 pmol/liter vs. 35 pmol/liter). Under the assumption that binding of TNF to sTNFR is a reversible reaction governed by the same equilibrium constant, $K_{\mathrm{D}} \geq 100 \mathrm{pmol} /$ liter (24), as binding of TNF to cell surface receptors, we must conclude that a sizable fraction of TNF molecules remains uncomplexed under the conditions of our experiment. This may explain our observation that even higher concentrations of recombinant sTNFR-A and sTNFR-B in plasma exhibit only a minor protective effect on TNF sensitive cells (Fig. 4). Previous reports also show that inhibition of TNF-mediated cytotoxicity requires a 100-fold molar excess of sTNFR-B over TNF $(19,21$, $25)$. However, it is possible that one or both sTNFR types exhibit better protection against those TNF-mediated effects that require only a brief exposure to the cytokine. The observation that normal plasma without measurable TNF concentration contains considerable amounts of sTNFR also suggests that the TNF-neutralizing capacity may not be the sole function of sTNFR in circulation. For instance, it is conceivable that STNFR exerts additional regulatory functions on cells expressing a membrane-anchored form of TNF (26).

In summary, our results demonstrate that under defined experimental conditions endotoxin first induces the release of TNF into circulation followed by a four- to fivefold increase in sTNFR plasma levels. While secretion of sTNFR-A is apparently related to the release of TNF, the secretion of sTNFR-B seems to be regulated differently. The levels of STNFR released into circulation after an endotoxin stimulus are not sufficient to block the preceeding TNF activity entirely, indicating that systemically released sTNFR may have additional functions of biological relevance.

\section{Acknowledgments}

We wish to thank Hansruedi Loetscher for providing purified recombinant sTNFR-A and sTNFR-B, and Werner Haas and Werner Lesslauer for valuable comments. The technical assistance of Wolfgang Eufe and Barbara Syllwasschy is gratefully acknowledged.

\section{References}

1. Tracey, K. J., H. Vlassara, and A. Cerami. 1989. Cachectin/tumour necrosis factor. Lancet. i:1122-1125.

2. Tracey, K. J., B. Beutler, S. F. Lowry, J. Merryweather, S. Wolpe, I. W. Milsark, R. J. Hariri, T. J. Fahey III, A. Zentella, J. D. Albert, et al. 1986. Shock and tissue injury induced by recombinant human cachectin. Science (Wash. DC). $234: 470-474$.
3. Grau, G. E., L. F. Fajardo, P.-F. Piguet, B. Allet, P.-H. Lambert, and P. Vassalli. 1987. Tumor necrosis factor (cachectin) as an essential mediator in murine cerebral malaria. Science (Wash. DC). 237:1210-1212.

4. Seckinger, P., S. Isaaz, and J.-M. Dayer. 1988. A human inhibitor to tumor necrosis factor $\alpha$. J. Exp. Med. 167:1511-1516.

5. Peetre, C., H. Thysell, A. Grubb, and I. Olsson. 1988. A tumor necrosis factor binding protein is present in human biological fluids. Eur. J. Haematol. 41:414-419.

6. Lantz, M., S. Malik, M. L. Slevin, and I. Olsson. 1990. Infusion of tumor necrosis factor (TNF) causes an increase in circulating TNF-binding protein in humans. Cytokine. 2:402-406.

7. Engelmann, H., D. Novick, and D. Wallach. 1990. Two tumor necrosis factor-binding proteins purified from human urine. Evidence for immunological cross-reactivity with cell surface tumor necrosis factor receptors. J. Biol. Chem 265:1531-1536.

8. Kohno, T., M. T. Brewer, S. L. Baker, P. E. Schwartz, M. W. King, K. K. Hale, C. H. Squires, R. C. Thompson, and J. L. Vannice. 1990. A second tumor necrosis factor receptor gene product can shed a naturally occurring tumor necrosis factor inhibitor. Proc. Natl. Acad. Sci. USA. 87:8331-8335.

9. Brockhaus, M., H. J. Schoenfeld, E. J. Schlaeger, W. Hunziker, W. Lesslauer, and H. Loetscher. 1990. Identification of two types of tumor necrosis factor receptors on human cell lines by monoclonal antibodies. Proc. Natl. Acad. Sci. USA. 87:3127-3131.

10. Hohmann, H. P., R. Remy, M. Brockhaus, and A. P. G. M. van Loon. 1989. Two different cell types have different major receptors for human tumor necrosis factor (TNF $\alpha$ ). J. Biol. Chem. 264:14927-14934.

11. Ryffel, B., M. Brockhaus, U. Dürmüller, and F. Gudat. 1991. TNF receptors in lymphoid tissues and lymphomas: source and site of action of tumor necrosis factor $\alpha$ (TNF $\alpha)$. Am. J. Pathol. 139:7-15.

12. Porteu, F., and C. F. Nathan. 1990. Shedding of tumor necrosis factor receptors by activated human neutrophils. J. Exp. Med. 172:599-607.

13. Michie, H. R., K. R. Manogue, D. R. Spriggs, A. Revhaug, S. O’Dwyler, C. Dinarello, A. Cerami, S. M. Wolff, and D. W. Wilmore. 1988. Detection of circulating tumor necrosis factor after endotoxin administration. N. Engl. J. Med. 318:1481-1486.

14. Martich, G. D., R. L. Danner, M. Ceska, and A. F. Suffredini. 1991. Detection of Interleukin 8 and tumor necrosis factor in normal humans after intravenous endotoxin: the effect of antiinflammatory agents. J. Exp. Med. 173:1021-1024.

15. Spinas, G. A., D. Bloesch, U. Keller, W. Zimmerli, and S. Cammisuli. 1991. Pretreatment with ibuprofen augments circulating tumor necrosis factor- $\alpha$ interleukin-6 and elastase during acute endotoxinemia. J. Infect. Dis. 163:89-95.

16. Spinas, G. A., D. Bloesch, M.-T. Kaufmann, U. Keller, and J.-M. Dayer. 1990. Induction of plasma inhibitors of interleukin 1 and TNF- $\alpha$ by endotoxin administration to normal humans. Am. J. Physiol. R993-R997.

17. Digel, W., F. Porzsolt, M. Schmid, F. Herrmann, W. Lesslauer, and M. Brockhaus. 1992. High levels of circulating soluble receptors for tumor necrosis factor in hairy cell leukemia and B-type chronic lymphocytic leukemia. J. Clin. Invest. 89:1690-1693.

18. Porteu, F., M. Brockhaus, D. Wallach, H. Engelmann, and C. F. Nathan. 1991. Human neutrophil elastase releases a ligand-binding fragment from the 75-kDa tumor necrosis factor (TNF) receptor. J. Biol. Chem. 266:18846-18853.

19. Loetscher, H., R. Gentz, M. Zulauf, A. Lustig, H. Tabuchi, J. Schlaeger, M. Brockhaus, H. Gallati, M. Manneberg, and W. Lesslauer. 1991. Recombinant 55-kDa tumor necrosis factor (TNF) receptor. Stoichiometry of binding to TNF $\alpha$ and TNF $\beta$ and inhibition of TNF activity. J. Biol. Chem. 266:18324-18329.

20. Peck, R., M. Brockhaus, and J. Frey. 1989. Cell surface tumor necrosis factor (TNF) accounts for monocyte- and lymphocytes-mediated killing of TNFresistent target cells. Cell. Immunol. 122:1-10.

21. Aderka, D., H. Engelmann, V. Hornik, Y. Skornick, Y. Levo, D. Wallach, and G. Kushtai. 1991. Increased serum levels of soluble receptors for tumor necrosis factor in cancer patients. Cancer Res. 51:5602-5607.

22. Dembic, Z., H. Loetscher, U. Gubler, Y.-C. E. Pan, H.-W. Lahm, R. Gentz, M. Brockhaus, and W. Lesslauer. 1990. Two human TNF receptors have similar extracellular, but distinct intracellular, domain sequences. Cytokine. 2:231-237.

23. Lantz, M., U. Gullbverg, E. Nilsson, and I. Olsson. 1990. Characterization in vitro of a human tumor necrosis factor-binding protein. J. Clin. Invest. 86:1396-1402

24. Hohmann, H., M. Brockhaus, P. Baeuerle, R. Remy, R. Kolbeck, and A. P. G. M. van Loon. 1990. Expression of the types A and B tumor necrosis factor (TNF) receptors is independently regulated, and both receptors mediate activation of the transcription factor NF-kB. J. Biol. Chem. 265:22409-22417.

25. Engelberts, I., S. Stephens, G. J. M. Francot, C. J. van der Linden, and W. A. Buurman. 1991. Evidence of different effects of soluble TNF-receptors on various TNF measurements in human biological fluids. Lancet. 338:515-516.

26. Kriegler, M., C. Perez, K. DeFay, I. Albert, and S. D. Lu. 1988. A novel form of TNF/cachectin is a cell surface cytotoxic transmembrane protein: ramifications for the complex physiology of TNF. Cell. 53:45-53. 